\title{
Pathological Aspects of Breast Cancer in Indonesian Females, Emphasizing on the Modified W.H.O. Classification
}

\author{
Gunawan Tjahjadi*, Goi Sakamoto ${ }^{\dagger}$, Didid Tjindarbumi ${ }^{\ddagger}$, Susumu Watanabe ${ }^{\S}$, Joedo Prihartono ${ }^{\prime \prime}$, \\ Yoshiyuki Ohno", Santoso Cornain", Esti Soetrisno", Endang Sri Roostini", Muchlis Ramli ${ }^{\ddagger}$, \\ Idral Darwis , Setyawati Budiningsih $^{\ddagger}$, Sadao Suzuki ${ }^{\natural}$, Nakako Kubo ${ }^{* *}$
}

\begin{abstract}
Abstrak
Angka kejadian kanker payudara sangat bervariasi di antara berbagai daerah geografik dan perbedaan perangai patologik serta aspek biologik mungkin menyebabkan perilaku klinik yang berbeda pada penyakit tersebut. Pada penelitian ini kami bermaksud meneliti persamaan dan perbedaan perangai histopatologik kanker payudara antara wanita Indonesia dan wanita Jepang. Tiga ratus kasus kanker payudara yang diobati di Rumah Sakit Umum Pusat Cipto Mangunkusumo (RSCM), Jakarta, Indonesia, selama 3 tahun (1988-1991), diteliti aspek histopatologinya. Sediaan-sediaan dianalisa dengan menggunakan klasifikasi yang dianjurkan oleh "Japanese Breast Cancer Society". Hasilnya dibandingkan dengan data yang diperoleh dari 446 kasus pada "Cancer Institute Hospital" (CIH), Tokyo, Jepang. Pada kasus kanker payudara di RSCM ditemukan $1.33 \%$ karsinoma non-invasif, $88.3 \%$ karsinoma duktal invasif dan $9.7 \%$ tipe khusus. Data kanker payudara di CIH menunjukkan $7.4 \%$ karsinoma non-invasif, $80.4 \%$ karsinoma duktal invasif dan $11.3 \%$ tipe khusus. Jumlah penderita kanker payudara Indonesia pada golongan usia 20-29 tahun tampak lebih tinggi daripada wanita Jepang. Pada kedua penelitian tersebut jumlah kanker payudara terbanyak pada golongan usia 40-49 tahun. Tumor yang ditemukan pada wanita Indonesia mempunyai ukuran yang lebih besar daripada wanita Jepang. Proporsi karsinoma musinosum dan karsinoma lobularis lebih tinggi pada wanita Jepang, sedangkan proporsi karsinoma medularis lebih tinggi pada wanita Indonesia.
\end{abstract}

\begin{abstract}
The incidence of breast cancer varies greally among geographic regions and differences in pathological patterns and biological aspects might result in different clinical behavior of the disease. In this study we would like to investigate the similarity and dissimilarity of histopathological patterns of breast cancer among the Indonesian and the Japanese females. Three hundred cases of breast carcinoma treated at Dr. Cipto Mangunkusumo Hospital (RSCM), Jakarta, within 3 years (1988-1991) were analysed for the various histophatological aspects. The specimens were reviewed using the classification recommended by the Japanese Breast Cancer Society. We also compared with the data of 446 Japanese breast cancer cases from the Cancer Institute Hospital (CIH), Tokyo, Japan. The RSCM cases had $1,33 \%$ noninvasive carcinoma, $88,3 \%$ invasive carcinoma and $9,67 \%$ special types. The CIH cases were $7,4 \%$ noninvasive carcinoma, 80,4\% invasive ductal carcinoma and 11,3\% special types. Compared to the Japanese females it was noticed that breast cancer cases had already occured more frequently at the younger age group (20-29 years) of the Indonesian females. However, the age distributions of both groups peaked at 40-49 years. Indonesian females had larger-sized tumors. The proportion of mucinous and lobular carcinomas were higher in Japanese females, while the proportion of medullary carcinoma was higher in Indonesian females.
\end{abstract}

Key words: breast cancer, histopathological patterns, new classification.

\footnotetext{
* Department of Anatomic Pathology, Faculty of Medicine University of Indonesia, Dr. Cipto Mangunkusumo National Central General Hospital, Jakarta 10430, Indonesia.

${ }^{\dagger}$ Department of Pathology, Cancer Institute Hospital, Tokyo 170, Japan

* Department of Surgery, Faculty of Medicine University of Indonesia, Dr. Cipto Mangunkusumo National Central General Hospital, Jakarta 10430, Indonesia.

$\$$ Department of Surgery, Cancer Institute Hospital, Tokyo 170, Japan

II Department of Community Medicine, Faculty of Medicine University of Indonesia, Jakarta 10320, Indonesia.

' Department of Preventive Medicine, Nagoya University, Nagoya 466, Japan.

${ }^{* *}$ Department of Preventive Medicine, Nagoya City University, Nagoya 467, Japan.
}

Breast cancer is a world-wide, very common and serious disease, and comprises a relatively high incidence, namely about $20 \%$ among all malignancy. ${ }^{1}$ It is also the commonest fatal cancer with an incidence of 22.2 per 100.000 person years. ${ }^{2}$ The incidence of breast carcinoma varies greatly among geographic regions, it is high in European countries, Canada, Australia, New Zealand, similar to those of the United 
States, some 6 times greater than those observed in Asia-Japan. ${ }^{3}$ In Australia, the age-standardized incidence rate was 55.6 per 100.000 person years, ${ }^{4}$ but in Japan the rate was $20 .^{5}$ The annual incidence of breast cancer in Japan has been reported to be lower (12.1-16 per 100.000 females) than in America (71.7 per 100.000 females), as stated in the Cancer incidence in Five Continents, IARC publications. ${ }^{3}$ In Indonesia, according to the various Pathology-based cancer registry, breast cancer ranked the second, succeeding the cervical cancer, with a relative frequency of $11.59 \% .^{6}$

These differences has attracted several investigators to look upon several aspects of breast cancer, with systematic epidemiological studies. In addition, further comparison has been studied by analyzing the pathological and biological aspects of the disease, among American and Japanese women, and found out that breast cancer among Japanese females is characterized by a relatively low incidence and good prognosis. $^{7,8}$

In order to better understand about the disease, such comparative studies are also needed to be implemented among Indonesian and Japanese women. Further analysis on histopathological features and biological behaviour of the disease would be a great contribution to the current methods of treatment and refinements in therapeutic regimens.

From the pathology standpoint of view, a number of biological factors and principles have been delineated which permit an increasingly accurate prediction of prognosis and benefit of therapy, such as : histologic type, histologic grade, tumor size and axillary lymph node status. Breast cancer presents in a great variety of histological patterns, including spesific types which have useful clinical correlates and prognostic implications. There are various classifications of breast cancer, and in Indonesia we used the classification of WHO $(1981)^{9}$ and that of McDivitt et al. ${ }^{10}$ Since 1989 we adopted the classification use in Japan, ${ }^{11}$ which is fundamentally the same as the WHO classification, with the addition of a subclassification of the invasive ductal carcinoma into 3 sub-types.

The purpose of this study is to analyse the various histological variations of breast cancer in the Indonesian females, adjusting it with the new classification and their frequencies, and to compare it with the results of the Cancer Institute, Tokyo, Japan.

\section{METHODS}

Three hundred cases of breast carcinoma were diagnosed and treated at the Dr. Cipto Mangunkusumo National Central General Hospital (RSCM) within 3 years (1988-1991). These cases were from operable cases and biopsy specimens only, accounting for 110 and 190 cases respectively. The size of the tumor was the largest diameter of the tumor measured on the cut surface of the gross spesimen as recorded in the pathology report. Lymph-node metastases, using the " $n$ " classification, were grouped from n0 to $\mathrm{n} 3$. Based on the histological examination of lymph nodes, they were classified as shown in Table 1 .

Table 1. Lymph nodes metastases classification

\begin{tabular}{|c|c|}
\hline "n" grouping & Lymph nodes involvement \\
\hline n0 & : no metastasis \\
\hline nla & : 1-3 positive axillary lymph nodes \\
\hline n1b & : 4 or more positive axillary lymph nodes \\
\hline $\mathrm{n} 2$ & : metastasis in subclavicular lymph nodes \\
\hline n3 & : metastasis in supraclavicular lymph nodes \\
\hline
\end{tabular}

Of the 110 operable cases, only in 40 cases the lymph nodes could be analysed.

Five microns histological specimens were stained with hematoxylin-eosin standard procedure, similarly applied in both the Indonesian and the Japanese breast cancer specimens.

The specimens were reviewed by three investigators (GT, ES) and (GS) during the consultation meetings, referring to the classification recommended by the Japanese Breast Cancer Society. Agreement on the final diagnosis was established by applying the standard criteria of specific histological typing.

\section{HISTOLOGICAL CLASSIFICATION USED IN JAPAN}

The Japanese Breast Cancer Society will adopt here after the new histological classification of breast tumors as shown in Table 2. 
Table 2. Histological Classification of Breast Tumors (Japanese Breast Cancer Society, 1984)

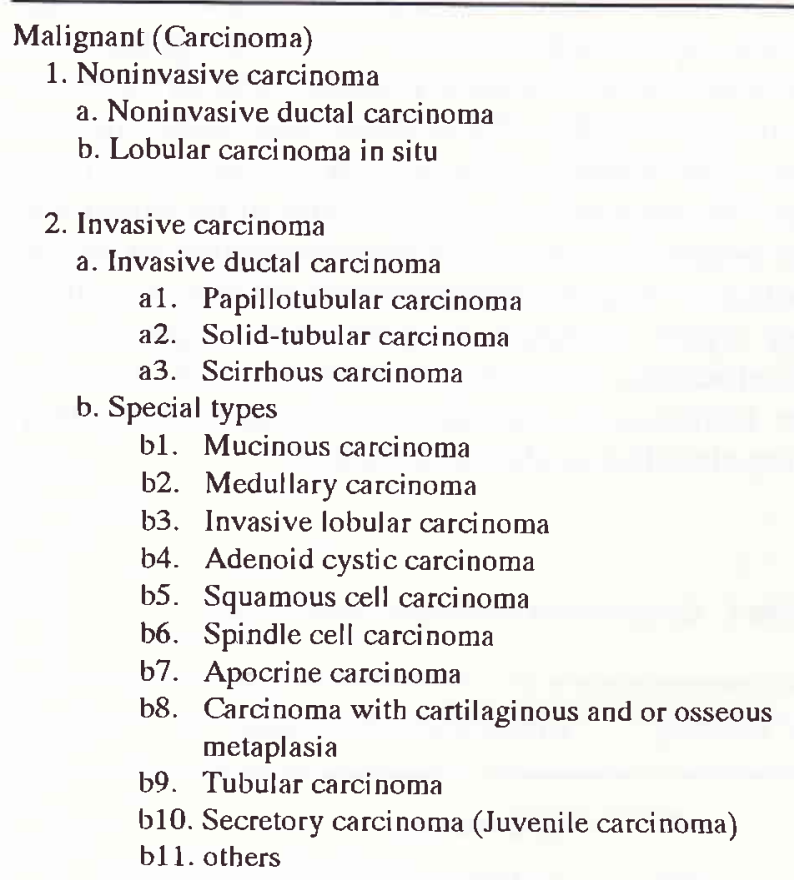

3. Paget's disease

Notes : See Appendix for the principles and details of classification

\section{RESULTS}

The case distribution by histological type is shown in Table 3.

Table 3. Histological Types and Case Distribution of Breast Cancer (1988-1991)

\begin{tabular}{lcc}
\hline Histological types & Number of Cases & $\%$ \\
\hline Noninvasive carcinoma & & \\
a. Noninvasive ductal ca & 4 & 1.33 \\
b. Lobular ca in situ & 0 & 0.00 \\
Invasive carcinoma & & \\
a. Invasive ductal carcinoma & 39 & 13.00 \\
a1. Papillotubular & 79 & 26.33 \\
a2. Solid-tubular & 147 & 49.00 \\
a3. Scirrhous & & \\
b. Special types & 4 & 1.33 \\
b1. Mucinous carcinoma & 17 & 5.68 \\
b2. Medullary carcinoma & 7 & 2.33 \\
b3. Invasive lobular carcinoma & 1 & 0.33 \\
b4. Adenoid cystic carcinoma & 2 & 0.67 \\
Paget's disease & 300 & 100.00 \\
\hline Totals & &
\end{tabular}

The most common was the invasive ductal carcinoma $(88.33 \%)$, followed by the special types $(9.67 \%)$, and the noninvasive carcinoma $(1.33 \%)$. Two out of three hundred were diagnosed as Paget's disease.

Among the invasive ductal carcinoma (2a), the scirrhous type was the most common accounted for $49 \%$ of the cases. Among the non invasive carcinoma, no lobular carcinoma in situ was found. In the special types, the medullary carcinoma was diagnosed in $5.68 \%$ of the cases.

The case distribution by age at operation/biopsy is given in table 4 .

Table 4. Case Distribution by Age at Operation/Biopsy

\begin{tabular}{ccr}
\hline Age at operation/biopsy & Number of cases & $\%$ \\
\hline $20-29$ & 13 & 4.33 \\
$30-39$ & 72 & 24.00 \\
$40-49$ & 93 & 31.00 \\
$50-59$ & 55 & 18.33 \\
$60-69$ & 58 & 19.33 \\
$70-79$ & 9 & 3.00 \\
\hline Totals & 300 & 100.00 \\
\hline
\end{tabular}

The age distribution showed the youngest case of 22 years old, and the oldest was 75 years old. The peak incidence was found in the 5th decade (31\%).

The location of the tumor in the left breast was found more frequent than in the right breast (see table 5), and $3.67 \%$ were bilateral.

Table 5. Case Distribution of Breast Cancer by Location

\begin{tabular}{lcc}
\hline Location & Number of cases & $\%$ \\
\hline Left breast & 172 & 57.33 \\
Right breast & 117 & 39.00 \\
Bilateral & 11 & 3.67 \\
\hline Totals & 300 & 100.00 \\
\hline
\end{tabular}

Only 6 of these operable cases have tumor smaller than $2 \mathrm{~cm}$ in diameter. Fifty five cases (50\%) have tumors more than $5 \mathrm{~cm}$ in diameter (see Table 6).

Table 6. Case Distribution by Size of Tumor assessed on surgical specimens of operable cases

\begin{tabular}{lcc}
\hline Size of tumor & Number of cases & $\%$ \\
\hline$<2 \mathrm{~cm}$ & 6 & 5.5 \\
$2.1-5 \mathrm{~cm}$ & 49 & 44.5 \\
$>5 \mathrm{~cm}$ & 55 & 50 \\
\hline Totals & 110 & 100.00 \\
\hline
\end{tabular}


The case distribution by tumor size of the whole cases, and compare with the cases from Cancer Institute Hospital $(\mathrm{CIH})$ is shown in Table 7.

Table 7. Case Distribution by Size of Tumor according to clinical assessment of all breast cancer cases

\begin{tabular}{lccccr}
\hline \multirow{2}{*}{ Size of tumor } & \multicolumn{2}{c}{ RSCM (1988-1991) } & & \multicolumn{2}{c}{ CIH (1989) } \\
\cline { 2 - 3 } \cline { 5 - 6 } & $\begin{array}{c}\text { Number of } \\
\text { cases }\end{array}$ & $\%$ & & $\begin{array}{c}\text { Number of } \\
\text { cases }\end{array}$ & $\%$ \\
\hline T 0 & - & & & 22 & 4.9 \\
T 1 & 6 & 2 & & 182 & 40.8 \\
T 2 & 51 & 17 & & 191 & 42.8 \\
T 3 & 87 & 29 & & 21 & 4.7 \\
T 4 & 156 & 52 & & 30 & 6.7 \\
\hline Totals & 300 & 100 & & 446 & 100
\end{tabular}

The data showed that $52 \%$ of the Indonesian breast cancer patients at Cipto Mangunkusumo Hospital (RSCM) were at advanced stage with T4 size, while such tumor was only found in $6.7 \%$ among the Japanese breast cancer patients at CIH. On the contrary early breast cancers with $\mathrm{T} 1$ size were only seen in $2 \%$ of the Indonesian females, while it was found in $40.8 \%$ of the Japanese females.

At RSCM, the majority (more than $80 \%$ ) were of $\mathrm{T} 3+\mathrm{T} 4$ size, while at $\mathrm{CIH}$ the majority (more than $80 \%$ ) were of $\mathrm{T} 1+\mathrm{T} 2$ size. In other words, at their presentation the tumor size of breast cancer among Indonesian females were larger than that among Japanese females.

In forty of the operable cases, the lymph node metastases could be analysed. The results are given in Table 8.

Table 8. Case Distribution by Lymph-node Metastases

\begin{tabular}{lcccccr}
\hline & \multicolumn{2}{c}{ RSCM (1988-1991) } & & \multicolumn{2}{c}{ CIH (1989) } \\
\cline { 2 - 3 } \cline { 5 - 6 } Lymph-node metastases & $\begin{array}{c}\text { Number of } \\
\text { cases }\end{array}$ & & \multicolumn{2}{c}{$\begin{array}{c}\text { Number of } \\
\text { cases }\end{array}$} & $\%$ \\
\hline Negative (n0) & 22 & 55 & & 229 & 51.3 \\
Axillary 1-3 (n1a) & 10 & 25 & 133 & 29.8 \\
Axillary 4 or more (nIb) & 8 & 20 & 62 & 13.9 \\
Subclavicular (n2) & - & - & 15 & 3.4 \\
Supraclavicular (n3) & - & - & 7 & 1.6 \\
\hline Totals & 40 & 100 & 446 & 100 \\
\hline
\end{tabular}

The data at the CIH showed that some patients underwent subclavicular and supraclavicular lymph node dissections, but at the RSCM lymph node dissections were limited to an axillary group. The rates were almost equal at the RSCM and CIH for the $\mathrm{n} 0$ and n1a. The incidence for n1b was $6.1 \%$ greater at the RSCM.

The comparative case distribution by histological types is shown in Table 9.

The RSCM cases had $1.33 \%$ noninvasive carcinoma, $88.33 \%$ invasive ductal carcinoma, and $9.67 \%$ special types. The $\mathrm{CIH}$ cases had $7.4 \%$ noninvasive carcinoma, $80.4 \%$ invasive ductal carcinoma, and $11.3 \%$ special types. The noninvasive carcinoma group, no lobular carcinoma in situ was found. The incidence of noninvasive duct carcinoma is much higher at the $\mathrm{CIH}$, with a $6.07 \%$ difference, than that at the RSCM.

Table 9. Histological Types and Case Distribution

\begin{tabular}{|c|c|c|c|c|}
\hline \multirow{2}{*}{ Histological types } & \multicolumn{2}{|c|}{ RSCM (1988-1991) } & \multicolumn{2}{|c|}{$\mathrm{CIH}(1989)$} \\
\hline & $\begin{array}{c}\text { Number of } \\
\text { cases }\end{array}$ & $\%$ & $\begin{array}{c}\text { Number of } \\
\text { cases }\end{array}$ & $\%$ \\
\hline \multicolumn{5}{|l|}{ Noninvasive carcinoma } \\
\hline a. Noninvasive ductal ca & 4 & 1.33 & 33 & 7.4 \\
\hline b. Lobular ca in situ & - & - & - & \\
\hline \multicolumn{5}{|l|}{ Invasive carcinoma } \\
\hline \multicolumn{5}{|l|}{ a. Invasive ductal ca } \\
\hline a1. Papillotubular & 39 & 13.00 & 86 & 19.3 \\
\hline a2. Solidtubular & 79 & 26.33 & 78 & 17.5 \\
\hline a3. Scirrhous & 147 & 49.00 & 194 & 43.6 \\
\hline \multicolumn{5}{|l|}{ b. Special types } \\
\hline b1. Mucinous ca & 4 & 1.33 & 16 & 3.6 \\
\hline b2. Medullary ca & 17 & 5.68 & 6 & 1.3 \\
\hline b3. Invasive lobular ca & 7 & 2.33 & 20 & 4.5 \\
\hline b4. Adenoid cystic ca & 1 & 0.33 & - & \\
\hline b5. Squamous cell ca & - & - & 1 & 0.2 \\
\hline b6. Spindle cell ca & - & - & 1 & 0.2 \\
\hline b7. Apocrine ca & - & - & 1 & 0.2 \\
\hline \multicolumn{5}{|l|}{ b8. Ca with cartil and/or } \\
\hline oss. metaplasia & - & - & - & \\
\hline b9. Tubular ca & - & - & 5 & 1.1 \\
\hline \multicolumn{5}{|l|}{ b10.Secretory ca } \\
\hline (Juvenile) & - & - & - & \\
\hline Paget's disease & 2 & 0.67 & 3 & 0.7 \\
\hline Totals & 300 & 100.00 & 445 & 100.0 \\
\hline
\end{tabular}




\section{DISCUSSION}

It was of great concern, that the majority of the Indonesian breast cancers found at their presentation were of much later stages in contrast to the Japanese counterpart.

The earlier detection of breast cancer could be responsible for the difference shown in Table 9 for the non-invasive types. In the invasive carcinoma group, the invasive ductal carcinoma is the most common, accounting for at least $80 \%$ of breast cancer. The incidence of $88.33 \%$ at the RSCM is similar with the report of Sakamoto et al. ${ }^{7}$ The scirrhous carcinoma is the most common type of invasive ductal carcinoma, with an incidence of about $50 \%{ }^{12}$ The data of the Indonesian breast cancers showed that the proportion of the solid-tubular carcinoma was higher than the papillotubular carcinoma, while the reverse was seen in the data of the Japanese breast cancer.

The sub-classification of invasive ductal carcinoma into 3 sub-types has prognostic significance. Such relationship has been observed by several investigators (Sakamoto G., personal communication). The papillotubular carcinoma shows the most favorable prognosis (ten-year survival rate $=77.4 \%$ ), and the scirrhous carcinoma shows the worst prognosis (tenyear survival rate $=61.2 \%$ ). The solid-tubular carcinoma showed a ten-year survival rate of $64.9 \%$. The invasive ductal carcinoma has been referred to as infiltrating duct carcinoma not otherwise specified (NOS) or no special type (NST). This group of carcinoma which is usually evaluated by histologic grading, ${ }^{13,} 14$ which will place these lesions into intermediate or high grade categories. ${ }^{15}$ This proposed new histologic al classification can be used instead of the grading system.

The special types of invasive breast cancer, including mucinous carcinoma, medullary carcinoma, tubular carcinoma in their pure form (more than 90\% homogeneity) have relatively favourable prognosis. ${ }^{4,16}$ Although invasive, these tumors show a low incidence of axillary lymph-node metastases and exhibit a long disease free interval. ${ }^{17,18}$

In both studies (RSCM and $\mathrm{CIH}$ ) the incidence of this special type is only about $10 \%$ of the whole breast cancer cases. This finding is similar with previous report by Sakamoto et al. ${ }^{7}$ In North America, some investigators estimated that special type cancer comprise $10 \%$ of all breast cancers, while others considered that they comprised between $25-30 \% .^{16}$

Mucinous carcinoma comprised only $1-6 \%$ of most series of invasive breast cancer, ${ }^{19}$ and the pure type approximately $2 \%$. At the RSCM it is $1.33 \%$, and at the $\mathrm{CIH}$, it is $3.6 \%$.

An interesting finding is that medullary carcinoma at the RSCM has a much higher incidence rate than that at the $\mathrm{CIH}$, with a difference of $4.38 \%$. Such type has been considered to represent more favourable prognosis.

The incidence of lobular carcinoma in Japan is very low and is significantly different from the incidence in Western countries. ${ }^{7}$ However Sugano and Sakamoto ${ }^{20}$ found that the incidence of lobular carcinoma among Japanese females has gradually increased. At the CIH before 1965 , the incidence was around $1 \%$ of all breast cancers, from 1971 to 1975 it was $3.4 \%$, and most recently, for 1974-1975, it has increased to 5.3\%. They concluded that the incidence of invasive lobular carcinoma among Japanese females is gradually approaching that of American females.

In 1989, the incidence of invasive lobular carcinoma at $\mathrm{CIH}$ was $4.5 \%$. At the RSCM, the incidence of invasive lobular carcinoma for 1981-1985 was $1.7 \%$ among 1265 cases of breast cancer, ${ }^{21}$ and in this study (1989-1992), it accounted for $2.33 \%$ among 300 cases of breast cancers.

No tubular carcinoma was found among the RSCM cases, but 5 cases were detected among the CIH cases of breast cancer. Tubular carcinomas are well differentiated tumors which show the highest rate of cure, among the special histologic type. ${ }^{22,23}$ Tubular carcinoma has received general recognition only in the last 10 years, since it is more common in groups of cancer detected by mammography, largely explaining the increased interest in recent years. ${ }^{24}$ This special type of breast cancer are more frequent in prevalent cancer (those detected at first screen by mammography) than cases detected subsequently at yearly intervals (incident cases). ${ }^{25}$ Whether this is true for the CIH cases is worthwile to be elucidated.

The peak incidence of breast cancer among Indonesian females was found in the 5 th decade, and was similar with the result at the $\mathrm{CIH}$ cases. The main difference with reference to the age distribution of breast carcinoma between Indonesia and Japanese females was in the 20-29 year age group. Thirteen cases were found among 300 breast cancer cases at the RSCM, while only 2 cases among Japanese females with breast cancer, in the 20-29 year age group. It seems that breast cancer occurs at the younger age group in the Indonesian females. 


\section{CONCLUSIONS}

At younger age group (20-29 years), breast cancer had already occured more frequently in the Indonesian females as compared to the Japanese females. However, the age distribution in both groups peaked at ages 40-49 years. Indonesian females had larger-sized tumors. The proportion of non-invasive carcinoma was lower among Indonesian females, while that of invasive ductal carcinoma was comparable in both groups. The proportion of mucinous carcinoma, lobular carcinoma were higher in Japanese females. It was of great interest, that medullary carcinoma, which has more favourable prognosis, occured in much higher proportion in Indonesian females.

\section{Acknowledgments}

The authors are indebted to the nurses and laboratory technicians for excellent care of surgicopathological specimens. This work was supported by the Ministry of Education and Culture, Japan, Grants No. 01042007 and 04042013; and was partly supported by the Indonesian Cancer Foundation. This collaborative study was a part of Special Cancer Research Project in Monbusho International Scientific Research Program, with the approval of the Dean, Faculty of Medicine, University of Indonesia, No. 4383 / PT02.H4.FK / E / 88.

\section{REFERENCES}

1. Gompel C, Van Kerkem C. The breast. In : Silverberg SG, ed. Principles and practice of surgical pathology. New York: John Wiley \& Sons, 1983:245-95.

2. Gilles GG, Amstrong BK, Smith IR. Cancer in Australia 1982. National Cancer Statistics Clearing House: Scientific Publication Number I, 1987:36-7.

3. Waterhouse JAH, Muir CS, Shanmugaratnam K, Powell J. Cancer incidence in tive continents. Lyon: IARC Scientific Publications, Nos. 15 and 42, 1976 and 1982.

4. Leong AS-Y, Raymond WA. Prognostic parameters in breast cancer. Pathology 1989;21:169-75.

5. Hanai A and Fujimoto I. Population-based cancer registries in Japan. In: Sasaki R, Aoki K, editors. Epidemiology \& prevention of cancer. Nagoya: The University of Nagoya Press, 1990:199-210.

6. Partoatmodjo M, Mangunkusumo R, Nasar IM, Prihartono J, Sudarsono S. Gambaran kanker di Indonesia tahun 1988 menurut data dari Histopatologi. Dalam : Kanker di Indonesia tahun 1989 data Histopatologi. Jakarta: Litbangkes Depkes/BRK-IAPI/YKI, 1990:96-112.

7. Sakamoto G, Sugano H, Hartman WH. Comparative pathological study of breast carcinoma among American and Japanese women. In : McGuire WL (Ed). Breast Cancer. Nashville: Plenum, 1981:211-31.
8. Rosen PP, Ashikari R, Thaler H, Ishikawa S, Hirota T, Abe $O$, et al. A comparative study of some pathological features of mammary carcinoma in Tokyo, Japan and New York, USA. Cancer 1977;39:429-34.

9. Hartmann WH, Ozello L, Sobin LH, Stalsberg H. Histological typing of breast tumours. In : International Histological Classification of Tumours, no 2. 2nd ed. Geneva : WHO, 1981.

10. Modivitt RW, Stewart FW, Berg JW. Tumours of the breast. In: Atlas of Tumor Pathology. 2nd series. Washington DC: AFIP, 1968.

11. Japanese Breast Cancer Society. The General Rules for Clinical and Pathological Recording of Breast Cancer. Jpn J Surg 1989;19:612-32.

12. Tjahjadi G, Sakamoto G, Comain S, Ohno Y. Pathological study of 100 cases of breast carcinoma, with special interest in histopathological typing. Indon J Oncol 1990; 2:1-14.

13. Elston CW, Grading of invasive carcinoma of the breast. In: Page, Anderson TJ. Diagnostic histopathology of the breast. Edinburgh: Churchill Livingstone, 1987:300-11.

14. Elston CW, Ellis IO. Pathology of breast screening. Histopathology 1990;16:109-18.

15. Page DL, Anderson TJ, Sakamoto G. Infiltrating carcinoma: major histological types. In : Page DL, Anderson TJ. Diagnostic Histology of the Breast. Edinburgh: Churchill Livingstone, 1987:193-235.

16. Page DL. Prognosis and breast cancer. Recognition of lethal and favorable prognostic types. Am J Surg Pathol 1991;15:334-49.

17. Adair F, Berg J, Joubert L, Robbins GF. Long-term follow up of breast cancer patients. The thirty year report. Cancer 1974;33: 1145-50.

18. Gallagar HS. Pathologic types of breast cancer : Their prognoses. Cancer 1984;53: 623-9.

19. Haagensen CD. Disease of the breast. $3^{\text {rd }}$ ed. Philadelphia : WB Saunders, 1986: 789-807.

20. Sugano H, Sakamoto G. Time trend data of breast cancer in Japan. Clinicophatological findings. Prev Med. 1978;168172.

21. Tjahjadi G, Soetrisno E, Laihad PF. Patologi tumor ganas payudara. Dalam : Cornain S, Tjahjadi G, Marwoto W, Setyawan S, ed. Tumor ganas pada wanita. Jakarta: PAFKUI 1986:79-106.

22. McDivitt RW, Boyce W, Gersell D. Tubular carcinoma of the breast. Clinical and pathological observations concerning 135 cases. Amer J Surg Pathol 1982;6:401-11.

23. Parl FF, Richardon LD. The histological and biological spectrum of tubular carcinoma of the breast. Pathol 1983; 14:694-8.

24. Patchefsky AS, Shaber GS, Schwartz GJ, Feig SA, Nerlinger RE. The pathology of breast cancer detected by mass population screening. Cancer 1977;40:1659-70.

25. Anderson TJ, Alexander F, Chetty U, Kirkpatrick A, Roberts MM, Lamb J, et al. Comparative pathology of prevalent and incident cancers detected by breast screening. Lancet 1986; 1:519-22. 


\section{Appendix}

\section{A. Principles of Classification}

1. Breast carcinoma is classified into three groups; noninvasive carcinoma, invasive carcinoma and Paget's disease.

2. Noninvasive carcinoma is classified into noninvasive ductal carcinoma and lobular carcinoma in situ; Invasive carcinoma into invasive ductal carcinoma and special types.

3. Invasive ductal carcinoma is further classified into three subgroups; papillotubular carcinoma, solid-tubular carcinoma and scirrhous carcinoma.

\section{B. Definition of Histological Types}

\section{Invasive carcinoma}

This group represents a carcinoma with invasion.

2a. Invasive ductal carcinoma

This is classified into three subgroups; papillotubular carcinoma, solid-tubular carcinoma and scirrhous carcinoma. Classification of invasive carcinoma follows the rule of predominancy when there are two or more histological patterns. In a case where judgement of the predominant type is difficult, the least differentiated type should be chosen as the histological type, with supplementary description of other histological types.

Remark 1: In practice, the predominant histological type should be taken for the principal classification, and the secondary histological type should be added as a supplementary description.

Remark 2: The degree of differentiation from poor to well is in order of scirrhous carcinoma, solidtubular carcinoma and papillotubular carcinoma.

Remark 3: A lesion with slight extraductal invasion should be so described for easier correspondence with the WHO classification.

2a1. Papillotubular carcinoma

This carcinoma is characterized by papillary projection and tubule formation, and may contain a solid pattern in part. Comedocarcinoma belongs to this type.

Remark 1: Comedocarcinoma should be identified as that

Remark 2: Papillary carcinoma which is an independent histological type in the WHO classification has been included in papillotubular carcinoma.

However there is still room for further consideration.

2a2. Solid-tubular carcinoma

This is a carcinoma characterized by a solid cluster of cancer cells with expansive growth forming sharp borders.

Note : since this type is characterized by distinct bounderies, tumors composed of medullary and/or solid nests are also included, even if interstitial components of stromal tissue are present. Central necrosis or fibrosis may also be evident.

2a3. Scirrhous carcinoma

Cancer cells of this histologic type show scattered invasion into the stroma in small clusters or in trabecular structures with accompanying desmoplasia of varying degrees.

There are two subtypes. One is a pure scirrhous carcinoma which has extremaly small amount of intraductal component and extensive stromal invasion. The other derives from papillotubular or solid-tubular carcinoma with a predominance of diffuse stromal invasion.

Note: The differential diagnosis between scirrhous carcinoma and solid-tubular carcinoma relies on the size of cancer nests and the fashion of infiltration at the tumor margin. Scirrhous carcinoma is composed of small nests, grows diffusely and infiltrates into the stromal tissue. On the other hand, solid-tubular carcinoma has large nests, grows expansively and is well circumscribed. 